\title{
Acute Silicoproteinosis: Therapy Success
}

\author{
Demet Karnak $^{\mathrm{a}}$ Gözde Köycüa $^{\mathrm{a}}$ Esra Erdemli $^{\mathrm{b}}$ Serpil Dizbay Sak ${ }^{\mathrm{c}}$ \\ Yusuf Kağan Kadıoğlud \\ Departments of ${ }^{\mathrm{a}}$ Chest Diseases, ${ }^{\mathrm{b}} \mathrm{Histology}$ and Embryology, and ${ }^{\mathrm{c} P a t h o l o g y, ~ F a c u l t y ~ o f ~ M e d i c i n e, ~ a n d ~}$ \\ ${ }^{\mathrm{d}}$ Department of Geological Engineering, Faculty of Engineering, Ankara University, Ankara, Turkey
}

A 39-year-old male with a 3-pack-year smoking history presented with exertional dyspnea for 1 month. $\mathrm{He}$ had been working in an iron-steel factory for 10 years and had been cleaning a dusty storage for the past 3 weeks. He had been given antibiotics for fever and had cyanosis upon admission. Computed tomography revealed bibasilar ground-glass opacities (fig. 1a). Laboratory analyses were normal except for high serum lipid/triglyceride lev- els. Hypoxemia $\left(\mathrm{PO}_{2}: 53 \mathrm{~mm} \mathrm{Hg}\right)$ and decreased lung diffusion capacity (DLCO: 62\% of predicted) were observed. The bronchoalveolar lavage fluid had a milky appearance. Transbronchial biopsy detected granular, eosinophilic, lipoproteinaceous material filling airspaces (fig. 1b). The industrial material, to which he had been exposed, was composed of fibrous material, identified as mainly silicon carbide on spectrometric analysis and X-
Fig. 1. a High-resolution computed tomography (HRCT) with patchy areas of ground-glass opacities, consistent with alveolar filling. b Transbronchial biopsy revealed lipoproteinaceous material filling airspaces. c Mineralogical investigation of the industrial dusty material showed silica particles on X-ray fluorescence. d Appearance of the lavage fluid samples from the left and right lungs. e HRCT with marked resolution of ground-glass opacities, after 7 months.
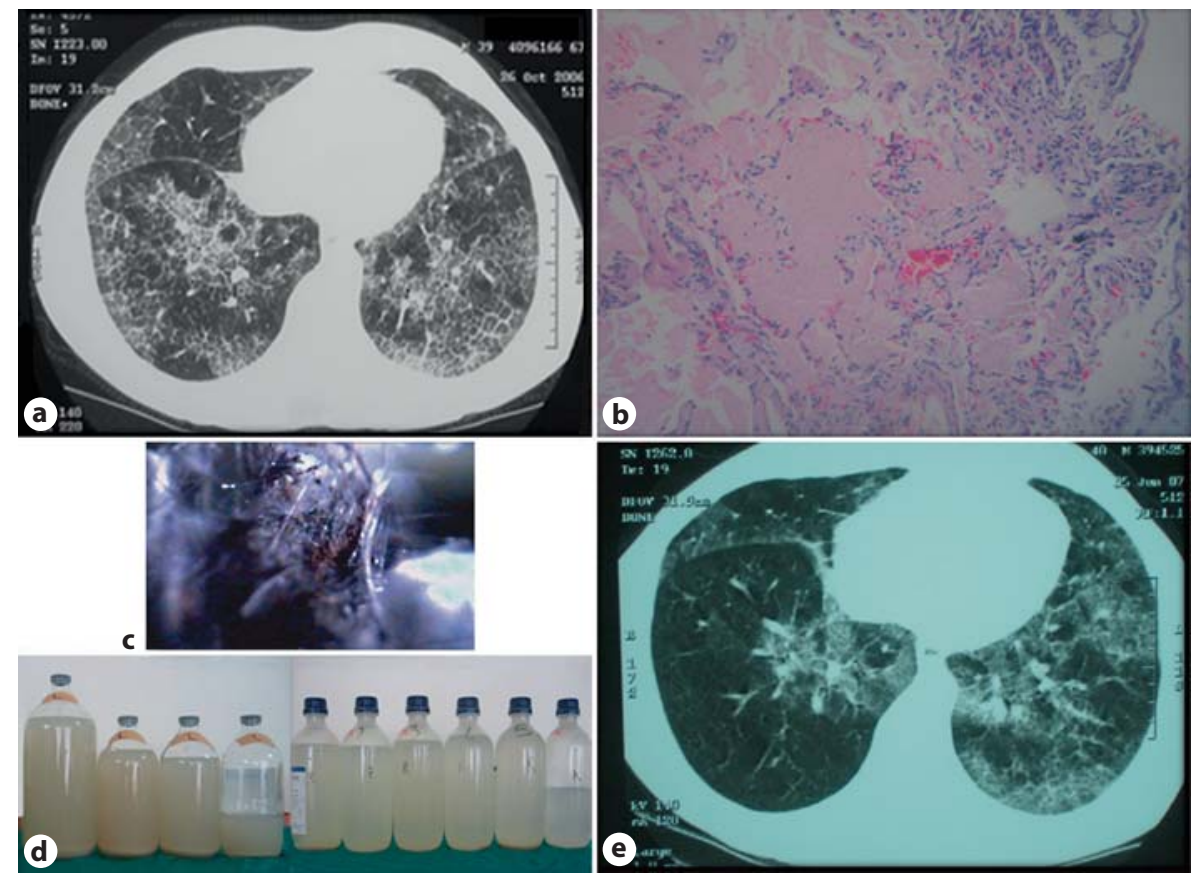

\section{KARGER}

Fax +4161306 1234 E-Mail karger@karger.ch www.karger.com
(C) 2011 S. Karger AG, Basel

$0025-7931 / 11 / 0826-0550 \$ 38.00 / 0$

Accessible online at: www.karger.com/res

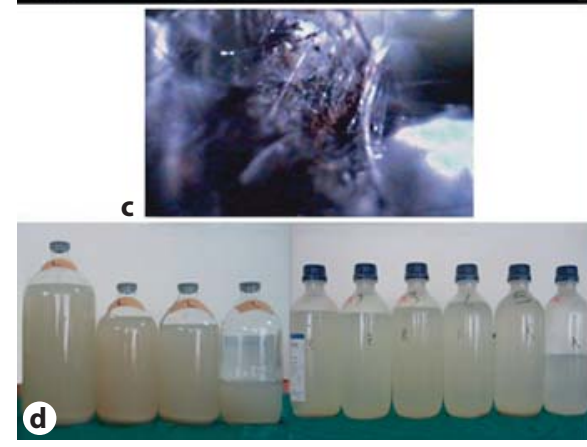

Prof. Demet Karnak, MD, FCCP

Department of Chest Diseases

Ankara University School of Medicine

TR-06100 Cebeci, Ankara (Turkey)

Tel. +90 312595 6572, E-Mail demet.karnak@gmail.com 
ray fluorescence (fig. 1c). He was diagnosed with acute silicoproteinosis. Whole lung lavage was performed first on the left and then on the right lung, 1 month apart, using 20 liters of saline for each procedure (fig. 1d). Marked clinical, physiological and radiological improvement was observed (fig. 1e). His blood oxygen level rose to $66 \mathrm{~mm}$ $\mathrm{Hg}$ and DLCO to $69 \%$ of predicted. Once he had changed his job there was no recurrence of the disease.

Acute silicosis is a fulminating respiratory illness resulting from relatively short exposure to high concentrations of fine silica dust [1]. Silicoproteinosis usually manifests as rapidly progressive shortness of breath often associated with constitutional symptoms, within 3 years of the initial exposure. The course of the disease is relentlessly progressive. Most of the reported cases have been fatal within months $[1,2]$. Fever is most probably secondary to infections, and high lipid levels in sera are also common in the course of the disease [2]. The alveolar spaces contain proteinous material which is relatively cell-free and strongly PAS positive, an appearance strikingly similar to that in idiopathic pulmonary alveolar proteinosis. This is why the same therapy, whole lung lavage, is a gold standard for both diseases $[1,2]$. However, some benefits of GM-CSF, plasmapheresis and good results with lung transplantation for advanced disease have also been shown [3]. In the current case, acute exposure of high-concentration silica particles might have caused the acute reaction, and previous exposures over 10 years might have contributed to the clinical picture revealed by successful therapy with whole lung lavage.

\footnotetext{
References

1 Marchiori E, Souza CA, Barbassa TG, Escuissato DL, Gasparetto EL, Souza AS Jr: Silicoproteinosis: high-resolution CT findings in 13 patients. AJR Am J Roentgenol 2007;189: 1402-1406.

2 Xipell JM, Ham KN, Price CG, Thomas DP: Acute silicoproteinosis. Thorax 1977;32: 104-111.

-3 Ioachimescu OC, Kavuru MS: Pulmonary alveolar proteinosis. Chron Respir Dis 2006; 3:149-159.
} 